\title{
MENAKAR KEWENANGAN DAN TANGGUNG JAWAB PEJABAT PEMBUAT AKTA TANAH (PPAT) DALAM PERSPEKTIF BESTUURS BEVOEGDHEID
}

\author{
Kadek Cahya Susila Wibawa \\ Fakultas Hukum, Universitas Diponegoro \\ JI. Prof. Soedarto, S.H., Tembalang, Semarang \\ kadekwibawa@lecturer.undip.ac.id
}

\begin{abstract}
The Government (BPN) has an obligation obtained by attribution to carry out land registration to ensure legal certainty in the land sector. The authority is then delegated to the Land Deed Official (PPAT), as a general official who is given the authority to make an authentic deed relating to land.The bestuurs bevoegdheid perspective explained that the source of authority obtained by the delegation, then the responsibility and accountability already lies with the recipient of the delegation (delegate). Based on this, the PPAT as a delegate, has administrative responsibility in the event of mall administration in the making of the authentic deed. The application of administrative sanctions is a form of responsibility that must be accepted by PPAT in the event of mall administration. The mall administrationcaused in a legal defect. The legal consequences for the PPAT deed which are legal defected, can be in the form of degradation of the strength of perfect evidence of an authentic deed (violation of formal requirements), and null and void or a cancellation of a deed in the event of a violation of material conditions.
\end{abstract}

Keywords: Land Deed Official; Authority; Bestuurs Bevoegdheid; Responsiblity; Administrative

\begin{abstract}
Abstrak
Pemerintah (BPN) mempunyai kewajiban yang diperoleh secara atribusi untuk melakukan pendaftaran tanah untuk menjamin kepastian hukum di bidang pertanahan. Kewenangan tersebut kemudian didelegasikan kepada Pejabat Pembuat Akta Tanah (PPAT), selaku pejabat umum yang diberikan kewenangan untuk membuat akta otentik yang berkaitan dengan tanah.Perspektif bestuurs bevoegdheid menjelaskan bahwa sumber wewenang yang diperoleh secara delegasi, maka tanggung jawab dan tanggung gugat sudah berada pada penerima delegasi (delegataris). Berdasarkan hal tersebut, maka PPAT selaku delegataris, memiliki tanggung jawab administrasi apabila terjadi mal administrasi dalam pembuatan akta otentik tersebut. Penerapan sanksi administrasi merupakan bentuk tanggung jawab yang harus diterima oleh PPAT apabila terjadi mal administrasi. Mal administrasi mengakibatkan akta cacat yuridis. Konsekuensi hukum terhadap akta PPAT yang cacat yuridis, dapat berupa terdegradasinya kekuatan bukti sempurna dari akta otentik (pelanggaran syarat formil), dan batal demi hukum atau dapat dibatalkannya suatu akta dalam hal pelanggaran syarat materiil.
\end{abstract}

Kata Kunci: PPAT; Wewenang; Bestuurs Bevoegdheid; Tanggung Jawab; Administrasi 


\section{A. Pendahuluan}

Masyarakat pada mulanya memanfaatkan tanah hanya sebatas sebagai tempat untuk tinggal atau yang berkaitan dengan perumahan dan sebagian besar untuk kegiatan yang berkaitan dengan pertanian, perkebunan, dan kehutanan. Seiring dengan perkembangan jaman, terjadinya globalisasi dan modernisasi, serta perkembangan ilmu pengetahuan dan teknologi; menyebabkan tanah tidak lagi semata-mata dipandang dengan kaca mata yang konservatif. Tanah mulai difungsikan sebagai pusat kegiatan industri, kegiatan usaha lainnya yang bernilai ekonomis, serta diperuntukkan sebagai bangunan-bangunan yang komersial atau bernilai ekonomis, dan peruntukan lainnya.

Mendasarkan pada Pasal 33 ayat (3) Undang-Undang Dasar Negara Republik Indonesia 1945 (UUD NRI 1945), menyatakan bahwa: "Bumi, air, dan kekayaan alam yang terkandung didalamnya dikuasai oleh Negara dan dipergunakan untuk sebesar-besarnya kemakmuran rakyat", sehingga pengelolaan pertanahan dalam pengendalian perubahan status tanah dari lahan pertanian menjadi lahan non pertanian perlu mendapat perhatian yang sangat serius, karena tanah merupakan sumber daya yang seharusnya membawa kemakmuran dan kesejahteraan bagi rakyat Indonesia. Ketentuan tersebut merupakan payung hukum yang utama di dalam pengelolaan sumber daya di Indonesia, termasuk pengelolaan pertanahan.

Kebutuhan akan permintaan terhadap tanah semakin meningkat seiring dengan perubahan fungsi tanah. Peningkatan permintaan tersebut ternyata berbanding terbalik dengan persediaan tanah yang semakin terbatas. Kondisi ini mengakibatkan nilai atau harga tanah yang semakin tinggi dan semakin menjauhkan dari kemampuan beli masyarakat terhadap tanah. Hal tersebut akan menjadi potensi besar timbulnya permasalahan sengketa pertanahan maupun konflik-konflik yang berhubungan dengan atau yang disebabkan oleh tanah. ${ }^{1} \mathrm{Hal}$ tersebut membutuhkanperangkat hukum (aturan) dan manajemen pertanahan yang tersusun rapi, teratur, dan sistematis dengan tujuan mencegah terjadinya konflik-konflik atau sengketa dalam bidang agraria atau pertanahan.

Salah satu pengawasan terhadap pengelolaan pertanahan di Indonesia adalah kegiatan pendaftaran tanah. Pasal 19 ayat (2) sub b Undang-Undang Nomor 5 Tahun 1960 Tentang Peraturan Dasar Pokok-Pokok Agraria (UUPA) mengatur bahwa sebagian tugas dan wewenang pemerintah (bestuurs bevoegdheid) dalam hal pendaftaran tanah dapat dibedakan menjadi dua tugas, yaitu: ${ }^{2}$

a. Pendaftaran hak atas tanah, adalah pendaftaran hak untuk pertama kalinya atau pembukuan suatu hak atas tanah dalam daftar buku tanah.

1 Dhea Tri Febriana \& Ahars Sulaiman, "Tanggung Jawab Pejabat Pembuat Akta Tanah (PPAT) Dalam Pembuatan Akta Jual Beli Tanah Berdasarkan Peraturan Pemerintah Republik Indonesia Nomor 24 Tahun 2016 Tentang PPAT", Jurnal Petita, Vol. 1, No. 1, Juni 2019, hlm. 125.

2 I Gusti Bagus Yoga Prawira, "Tanggung Jawab PPAT Terhadap Akta Jual Beli Tanah", Jurnal IUS, Vol. 4, No. 1, April 2016, hlm. 64. 
b. Pendaftaran peralihan hak atas tanah.

Lebih lanjut dalam Pasal 1 ayat (1) Peraturan Pemerintah Nomor 24 Tahun 1997 Tentang Pendaftaran Tanah, menyebutkan:

Pendaftaran tanah adalah rangkaian kegiatan yang dilakukan oleh Pemerintah secara terus-menerus, berkesinambungandan teratur, meliputi pengumpulan, pengolahan, pembukuan dan penyajian serta pemeliharaan data fisik dan data yuridis, dalam bentuk peta dan daftar, mengenai bidangbidang tanah dan satuan-satuan rumah susun, termasuk surat pemberian tanda bukti haknyabagi bidang-bidang tanah yang sudah ada haknya dan hak milik atas satuan rumah susun serta hak-hak tertentu yang membebaninya.

Berkaitan dengan pendaftaran tanah tersebut, masyarakat memerlukan kepastian hukum dalam pelayanan jasa yang berkaitan dengan pendaftaran tanah. Peraturan perundangundangan di Indonesia mengatur hal yang berkaitan dengan jasa pelayanan masyarakat atau jabatan yang berhubungan dengan kepentingan akan tanah melalui Pejabat Pembuat Akta Tanah (PPAT). Pasal 1 angka 1 Peraturan Pemerintah Republik Indonesia Nomor 24 Tahun 2016 Tentang Perubahan Atas Peraturan Pemerintah Nomor 37 Tahun 1998 Tentang Peraturan Jabatan Pejabat Pembuat Akta Tanahmenyebutkan bahwa: "Pejabat Pembuat Akta Tanah, selanjutnya disebut PPAT, merupakan pejabat umum yang diberi kewenangan untuk membuat akta-akta otentik mengenai perbuatan hukum tertentu mengenai hak atas tanah atau hak milik atas satuan rumah susun".

Jumlah PPAT yang tercatat sampai Pebruari 2019 di Indonesia adalah sebanyak 15.138 orang PPAT. ${ }^{3}$ PPAT mempunyai peranan yang sangat vital di dalam kegiatan pendaftaran tanah di Indonesia. Pasal 2 Peraturan Pemerintah Nomor 37 Tahun 1998 Tentang Peraturan Jabatan Pejabat Pembuat Akta Tanah, menyatakan sebagai berikut:

1. PPAT mempunyai tugas pokok melaksanakan sebagian kegiatan pendaftaran tanah dengan membuat akta sebagai bukti telah dilakukannya perbuatan hukum tertentu mengenai hak atas tanah atau hak milik atas satuan rumah susun, yang akan dijadikan dasar bagi pendaftaran perubahan data pendaftaran tanah yang diakibatkan oleh perbuatan hukum itu.

2. Perbuatan hukum sebagaimana dimaksud pada ayat (1) adalah sebagai berikut:
a. Jual beli.
b. Tukar menukar.
c. Hibah.
d. Pemasukan ke dalam perusahaan (inbreng).
e. Pembagian hak bersama.

3 Tim Penyusun Naskah Akademik dan Rancangan Undang-Undang Tentang Jabatan Pejabat Pembuat Akta Tanah, 2019, Naskah Akademik dan Rancangan Undang-Undang Tentang Jabatan Pejabat Pembuat Akta Tanah, Jakarta, Badan Keahlian Dewan Perwakilan Rakyat Republik Indonesia, hlm. 11. 
f. Pemberian hak guna bangunan/hak pakai atas tanah hak milik.

g. Pemberian hak tanggungan.

h. Pemberian kuasa membebankan hak tanggungan.

Uraian singkat mengenai tugas pokok PPAT tersebut, menggambarkan kedudukan PPAT yang sangat unik untuk dikaji. Secara yuridis PPAT tergolong sebagai pejabat umum yang diangkat dan diberhentikan oleh Menteri. PPAT secara yuridis menjalankan sebagian urusan pemerintahan di bidang pertanahan (menjalankan kewenangan eksekutifatau bestuurs bevoegdheid). PPAT diangkat oleh pemerintah, dalam hal ini Badan Pertanahan Nasional (BPN) dengan tugas dan kewenangan tertentu dalam rangka melayani kebutuhan masyarakat akan akta pemindahan hak atas tanah, akta pembebanan hak atas tanah, dan akta pemberian kuasa pembebanan hak tanggungan sebagaimana diatur dalam peraturan perundangundangan yang berlaku. ${ }^{4}$ PPAT bahkan diberi kewenangan (bevoegdheid) untuk menggunakan stempel yang berlogo lambang negara "Garuda Pancasila". Hal yang menarik adalah bahwa PPAT tidak digaji oleh Negara meskipun tergolong sebagai pejabat umum, dan PPAT dibenarkan secara normatif untuk menerima imbalan jasa atas pekerjaan yang dilakukannya dalam bidang pertanahan, sesuai peraturan perundang-undangan yang berlaku. Hal tersebutlah yang membuat kedudukan PPAT menjadi unik dan berbeda dibandingkan dengan pejabat umum lainnya, baik pejabat negara atau pejabat daerah. Kedudukan PPAT seperti yang terurai tersebut menimbulkan implikasi lebih lanjut berkaitan dengan kewenangan dan tanggung jawab PPAT, serta akibat hukum terhadap akta cacat yuridis yang dibuat oleh atau di hadapan PPAT dengan mendasarkan pada perspektif.

Mendasarkan pada uraian tersebut di atas, maka tulisan ini mengambil judul: "Menakar Kewenangan Dan Tanggung Jawab Pejabat Pembuat Akta Tanah (PPAT) Dalam Perspektif Bestuurs Bevoegdheid". Rumusan masalah dan titik tolak kajian dalam tulisan ini, antara lain: 1) Bagaimana kewenangan Pejabat Pembuat Akta Tanah (PPAT) dalam perspektif bestuurs bevoegdheid? 2) Bagaimana tanggung jawab administratif Pejabat Pembuat Akta Tanah (PPAT) terhadap akta yang cacat yuridis dalam perspektif besruurs bevoegdheid? 3) Bagaimana konsekuensi hukum terhadap akta cacat yuridis yang dibuat oleh atau di hadapan Pejabat Pembuat Akta Tanah (PPAT) dengan mendasarkan pada perspektif besruurs bevoegdheid?

\footnotetext{
4 Jimly Asshiddiqie, "Independensi Dan Akuntabilitas Pejabat Pembuat Akta Tanah", Jurnal Renvoi, Vol.
} 3, Juni 2003, hlm. 31. 


\section{B. Pembahasan}

\section{Kewenangan Pejabat Pembuat Akta Tanah (PPAT) Dalam Perspektif Bestuurs Bevoegdheid}

Pemerintah secara umum menjalankan tiga fungsi utama yang didasarkan pada wewenang publik (bestuurs bevoegdheid), yaitu: menjalankan fungsi normatif atau legitimasi (normative-legitimerende functie), menjalankan fungsi instrumental (instrumentele functie), dan menjalankan fungsi jaminan atau perlindungan (waarborg functie). Pelaksanaan wewenang publik (bestuurs bevoegdheid) dijalankan dengan berlandaskan pada:

1. Asas negara hukum (rechtstaatatau rule of law).

Salah satu pilar utama negara hukum (rechtstaatatau rule of law), yaitu adanya asas legalitas (wetmatigheid van bestuur) dalam penyelenggaraan pemerintahan. Hal tersebut bermakna bahwa setiap wewenang atau kewenangan yang dimiliki oleh badan atau pejabat tata usaha negara, hanya diperoleh dengan didasarkan atas ketentuan peraturan perundang-undangan yang berlaku.

2. Asas demokrasi.

Hal yang terpenting dalam penyelenggaraan pemerintahan wajib mendasarkan pada prinsip penyelenggaraan pemerintahan dari, oleh, dan untuk rakyat, sehingga dalam pelaksanaannya perlu mempertimbangkan keterwakilan rakyat melalui badan perwakilan rakyat. Asas demokrasi juga menuntut keterbukaan pemerintah dan peningkatan peran serta masyarakat (inspraak) dalam pengambilan keputusan.

3. Asas instrumental.

Asas ini menekankan bahwa penyelenggaraan pemerintahan yang didasarkan pada wewenang publik selayaknya memperhatikan asas efisiensi (doelmatigheid) dan asas efektivitas (doeltreffendheid).

Mendasarkan pada asas legalitas dalam penyelenggaraan pemerintahan tersebut, maka tanpa ada dasar wewenang yang diberikan oleh suatu peraturan perundang-undangan, maka semua badan atau pejabat tata usaha negara, termasuk BPN dan PPAT tidak akan memiliki wewenang yang dapat mempengaruhi keadaan atau kondisi hukum warga masyarakatnya.

Lebih lanjut asas wetmatigheid van bestuur tersebut diturunkan ke dalam Pasal 1 ayat (2) Undang-Undang Nomor 5 Tahun 1986 juncto Undang-Undang Nomor 9 Tahun 2004 Tentang Perubahan Atas Undang-Undang Nomor 5 Tahun 1986 Tentang Peradilan Tata Usaha Negara, yang menyatakan, "Badan atau Pejabat Tata Usaha Negara adalah Badan atau Pejabat yang melaksanakan urusan pemerintah berdasarkan peraturan perundang-undangan yang berlaku". Berkaitan dengan PPAT, maka ketentuan tersebut kemudian bersinergi dengan Pasal 1 angka 1 Peraturan Pemerintah Republik Indonesia Nomor 24 Tahun 2016 Tentang Perubahan Atas Peraturan Pemerintah Nomor 37 Tahun 1998 Tentang Peraturan Jabatan Pejabat Pembuat Akta Tanah menyebutkan bahwa: "Pejabat Pembuat Akta Tanah, selanjutnya disebut PPAT, 
merupakan pejabat umum yang diberi kewenangan untuk membuat akta-akta otentik mengenai perbuatan hukum tertentu mengenai hak atas tanah atau hak milik atas satuan rumah susun".

Pemerintah diberi kewenangan untuk menyelenggarakan pendaftaran tanah sebagaimana amanat Pasal 19 ayat (1)UUPA. Hal tersebut untuk menjamin kepastian hukum dalam bidang pertanahan, karena pendaftaran merupakan satu-satunya pembuktian dan pendaftaran merupakan syarat sahnya peralihan hak. ${ }^{5}$ Ketentuan tersebut menjadi dasar didapatkannya Kewenangan atributif ${ }^{6}$ kepada Pemerintah untuk melaksanakan pendaftaran tanah. Kewenangan atribusi tersebut merupakan bentuk penugasan oleh hukum atas wewenang kepada suatu badan atau pejabat administrasi (pemerintah). Lebih lanjut Pasal 6 ayat (2) Peraturan Pemerintah Nomor 24 Tahun 1997 Tentang Pendaftaran Tanah, pemerintah melimpahkan atau mengalihkan kewenangan tersebut kepada PPAT. Hal tersebut berarti kewenangan pendaftaran tanah yang dimiliki oleh PPAT diperoleh secara delegasi (kewenangan delegatif). Berdasarkan hierarki peraturan perundang-undangan terlihat jelas alur pemahaman tentangbagaimana pemerintah (BPN) mendapatkan wewenang atributif dan berdasarkan wewenang tersebut didelegasikan kepada PPAT. Pengalihan wewenang dari BPN kepada PPAT sebagai delegataris, mengakibatkan tanggung jawab dan tanggung gugat beralih pada delegataris (PPAT). Mendasarkan pada hal tersebut, maka BPN (pemberi wewenang) tidak dapat menggunakan wewenang itu lagi, kecuali setelah ada pencabutan dengan berpegang pada asas "contrarius actus". 7

\section{Tanggung Jawab Administratif Pejabat Pembuat Akta Tanah (PPAT) Terhadap Akta Yang Cacat Yuridis Dalam Perspektif Bestuurs Bevoegdheid}

Produk akta PPAT berpotensi menimbulkan masalah atau sengketa apabila terdapat adanya penyimpangan syarat sahnya perjanjian jual beli tanah dan bangunan serta adanya penyimpangan terhadap tata cara pembuatan akta yang menyangkut syarat materil (baik subyek maupun obyeknya) dan syarat formil (prosedur dan persyaratan). ${ }^{8}$ Seorang PPAT dalam

5 Boedi Harsono, 2003, Hukum Agraria Indonesia: Sejarah Pembentukan Undang-Undang Pokok Agraria, Isi dan Pelaksanaannya, Jakarta, Djambatan, hlm. 12; sebagaimana dikutip kembali oleh Dona Christin, "Analisis Atas Diketahuinya Cacat Yuridis Pada Akta Jual Beli Tanah Dan Rumah Yang Dibuat Oleh PPAT (Putusan Mahkamah Agung No. 2333 K/Pdt/2015)”, Premise Law Journal, Vol. 14, Issue 3, 2017, hlm. 2.

6 Secara umum dalam hukum administrasi negara, disebutkan sumber wewenang dapat diklasifikasi menjadi dua, yaitu: atribusi dan pelimpahan wewenang, baik secara delegasi maupun secara mandat. Kewenanganatribusi (atributif) merupakan wewenang asli yang diperoleh langsung atau merupakan pencipataan wewenang oleh legislator. Delegasi merupakan pelimpahan atau pengalihan wewenang oleh suatu badan administrasi kepada badan administrasi lain, untuk mengambil keputusan yang pelaksanaannya di bawah tanggung jawabnya sendiri (badan/pejabat penerima delegasi). Mandat merupakan wewenang yang dilimpahkan kepada mandataris (penerima mandat) yang sewaktu-waktu dapat ditarik oleh mandataris.

7 Philipus M. Hadjon, 2015, Pengantar Hukum Administrasi Indonesia, Yogyakarta, Gadjah Mada University Press, hlm. 121.

8 AdrianSutedi, 2008, Peralihan Hak Atas Tanah, Jakarta, Sinar Grafika, hlm. 77. 
menjalankan tugas dan kewenangan jabatannya tersebut, khususnya berkaitan dengan prosedur pembuatan akta PPAT adakalanya melakukan kesalahan, dan kesalahan tersebut bisa saja menyangkut persyaratan formil maupun materil, misalnya: kesalahan mengenai ketidakwenangan PPAT dalam membuat akta otentik, yang berakibat hilangnya otensitas akta yang dibuatnya, atau kekuatan pembuktian akta tersebut tidak lagi sebagai alat bukti yang lengkap atau sempurna, di antara dan bagi pihak-pihak yang berkepentingan, melainkan menjadi akta atau surat di bawah tangan, dimana kesalahan tersebut bisa saja dilakukan dengan sengaja maupun tidak disengaja. ${ }^{9}$

Peraturan perundang-undangan menegaskan bahwa pertanggungjawaban yang PPAT bukan hanya pertanggungjawaban dalam arti sempit yaitu pertanggungjawaban yang berkaitan dengan membuat akta, tetapi dituntut pula pertanggungjawaban dalam arti yang luas, yaitu tanggung jawab pada saat tahapan akta dibuat dan tanggung jawab pada saat pasca penandatanganan akta.

Tanggung jawab PPAT sebagai sebuah profesi dapat dikelompokkan menjadi dua yaitu: tanggung jawab etik (berkaitan dengan etika profesi) dan tanggung jawab hukum. Tanggung jawab hukum ini dapat berupa: tanggung jawab berdasarkan hukum pidana, hukum perdata dan hukum administrasi. Perspektif bestuurs bevoegdheid dapat dipakai sebagai kaca mata untuk menilai tanggung jawab PPAT dari hukum administrasi dalam kaitannya dengan akta cacat yuridis yang dibuat oleh PPAT.PPAT sangat memungkinkan untuk melakukan suatu kekhilafan atau kekeliruan yang sifatnya administratif atau biasa disebut dengan mal administrasi. Konsekuensi hukum terhadap hal tersebut adalah PPAT dapat dimintai pertanggungjawabannya secara administratif.

Tugas dan wewenang PPAT telah diatur dalam Pasal 2 Peraturan Pemerintah Republik Indonesia Nomor 24 Tahun 2016 Tentang Perubahan Atas Peraturan Pemerintah Nomor 37 Tahun 1998 Tentang Peraturan Jabatan Pejabat Pembuat Akta Tanah. Pembuatan akta yang mengandung cacat yuridis oleh PPAT dapat dikategorikan sebagai perbuatan yang menyalahgunakan wewenang. Hal tersebut karena wewenang PPAT sebagaiman yang telah diatur telah disimpangi, sehingga penggunaan wewenang tersebut pada akhirnya tidak sesuai dengan tujuan pemberian wewenang itu sendiri, sehingga dalam hal ini nampak telah terjadi penyalahgunaan wewenang oleh PPAT karena tidak menjalankan wewenang sebagaimana mestinya.

PPAT wajib mengambil sikap teliti berhati-hati dalam hal pembuatan akta otentik, karena PPAT harus mempunyai profesionalitas secara teoritis maupun praktis. Keadaan penyalahgunaan wewenang ini akan semakin jelas apabila terdapat unsur merugikan yang diderita oleh salah satu atau para pihak yang tampak pada saat dibatalkannya akta PPAT yang

9 Dhea Tri Febriana \& Ahars Sulaiman, Op.cit, hlm. 131. 
dibuatnya sebagai konsekuensi final dari akta yang mengalami cacat hukum. Peraturan Kepala Badan Pertanahan Nasional Nomor 1 Tahun 20016 Tentang Ketentuan Pelaksanaan Peraturan Pemerintah Nomor 37 Tahun 1998 Tentang Peraturan Jabatan Pejabat Pembuat Akta Tanah menyatakan bahwapenyimpangan terhadap syarat formil dan materil yang dilakukan oleh PPAT termasuk pelanggaran berat. Pelanggaran berat tersebut dapat dikenakan sanksi pemberhentian dengan tidak hormat dari jabatannya oleh Kepala Badan Pertanahaan Nasional Indonesia.

Lebih lanjut dalam Pasal 62 Peraturan Pemerintah Nomor 24 Tahun 1997 Tentang Pendaftaran Tanah disebutkan bahwa PPAT yang dalam melaksanakan tugasnya mengabaikan ketentuan-ketentuan sebagaimana dimaksud dalam Pasal 38, Pasal 39 dan Pasal 40 serta ketentuan dan petunjuk yang diberikan oleh Menteri atau Pejabat yang ditunjuk dikenakan tindakan administratif berupa teguran tertulis sampai pemberhentian dari jabatannya sebagai PPAT, dengan tidak mengurangi kemungkinan dituntut ganti kerugian oleh pihak-pihak yang menderita kerugian yang diakibatkan oleh diabaikannya ketentuan-ketentuan tersebut.

Tanggung jawab administratif berupa teguran tertulis sampai dengan pemberhentian jabatannya sebagai PPAT sebagaiman diatur dalam Pasal 62 Peraturan Pemerintah Nomor 24 Tahun 1997 Tentang Pendaftaran Tanah sejalan dengan ketentuan dalam Pasal 10 Peraturan Pemerintah Republik Indonesia Nomor 24 Tahun 2016 Tentang Perubahan Atas Peraturan Pemerintah Nomor 37 Tahun 1998 Tentang Peraturan Jabatan Pejabat Pembuat Akta Tanahdan Pasal 6 ayat (1) Kode Etik Ikatan Pejabat Pembuat Akta Tanah (IPPAT), yaitu bagi anggota yang melakukan pelanggaran Kode Etik dapat dikenai sanksi berupa:
a. Teguran.
b. Peringatan.
c. Schorsing (pemecatan sementara) dari keanggotaan IPPAT.
d. Onzetting (pemecatan) dari keanggotaan IPPAT.
e. Pemberhentian dengan tidak hormat dari keanggotaan IPPAT.

Tanggung jawab PPAT secara administratif ini, dapat pula berupa sanksi denda, terutama yang berkaitan dengan kewenangan perpajakan, yang merupakan kewenangan tambahan PPAT yang diberikan oleh undang-undang perpajakan. Pasal 91 ayat (1) Undang-Undang Nomor 28 Tahun 2009 Tentang Pajak Daerah Dan Retribusi Daerah, yang secara tegas menyatakan bahwa Pejabat Pembuat Akta Tanah/Notaris hanya dapat menandatangani akta pemindahan Hak atas Tanah dan/atau Bangunan setelah Wajib Pajak menyerahkan bukti pembayaran pajak". Implikasi dari ketentuan tersebut adalah PPAT dapat dikenakan sanksi sebagaimana yang diatur dalam Pasal 93 Undang-Undang Nomor 28 Tahun 2009 Tentang Pajak Daerah Dan Retribusi Daerah, bahwa Pejabat Pembuat Akta Tanah/Notaris dan kepala kantor yang membidangi pelayanan lelang negara, yang melanggar ketentuan sebagaimana 
dimaksud dalam Pasal 91 ayat (1) dan ayat (2) dikenakan sanksi administratif berupa denda sebesar Rp.7.500.000,00 (tujuh juta lima ratus ribu rupiah) untuk setiap pelanggaran.

\section{Konsekuensi Hukum Terhadap Akta Cacat Yuridis Yang Dibuat Oleh Atau Di Hadapan Pejabat Pembuat Akta Tanah (PPAT) Dengan Mendasarkan Pada Perspektif Bestuurs Bevoegdheid}

Persoalan ketiga yang muncul sebagai akibat dari PPAT yang melakukan mal administrasi, yaitu akta PPAT menjadi cacat yuridis (legal defect). Akibat hukum dari akta PPAT yang tidak sesuai dengan prosedur pembuatan akta PPAT yang mengakibatkan cacat hukum dapat disebabkan, karena adanya:

a. Penyimpangan terhadap syarat formil.

Pasal 1868 KUHPerdata menyebutkan bahwa unsur-unsur pembuatan akta otentik harus memenuhi:

1. Akta harus dibuat dalam bentuk yang ditentukan oleh undang-undang.

2. Akta harus dibuat oleh door atau dihadapan ten overstaan seorang pejabat umum.

Berpijak pada syarat-syarat untuk terpenuhinya suatu akta otentik sebagaimana diatur pada Pasal 1868 KUHPerdata, maka apabila dikaitkan dengan ketentuan Pasal 95-102 Peraturan Menteri Negara Agraria/Kepala BPN Nomor 3 Tahun 1997 Tentang Ketentuan Pelaksanaan Peraturan Pemerintah Nomor 24 Tahun 1997 Tentang Pendaftaran Tanah; maka apabila ketentuan atau syarat formil tersebut dilanggar oleh PPAT, akan menyebabkan terdegradasinya kekuatan bukti sempurna dari akta otentik tersebut menjadi kekuatan bukti akta dibawah tangan apabila berdasarkan putusan pengadilan menyatakan adanya salah satu atau lebih pelanggaran yang dilakukan.

b. Penyimpangan terhadap syarat materil.

Pasal 1320 KUHPerdata menyatakan bahwa syarat sahnya suatu perjanjian harus memenuhi empat syarat, yaitu:

a. Kesepakatan para pihak yang mengikatkan diri.

b. Kecakapan para pihak dalam membuat suatu perjanjian.

c. Suatu hal tertentu.

d. Kausa yang halal atau tidak terlarang.

Menurut Subekti: ${ }^{10}$

Ketentuan Pasal 1320 KUHPerdata tersebut menunjukkan bahwa syarat tersebut bersifat kumulatif artinya setiap perjanjian yang dibuat harus memenuhi keempat persyaratan tersebut secara bersama-sama. Tidak dipenuhinya salah satu syarat dalam ketentuan Pasal 1320 KUHPerdata tersebut, mengakibatkan perjanjian cacat

10 Subekti, 2001, Hukum Perjanjian, Jakarta, Intermasa, hlm.17. 
hukum, yang keabsahannya dapat dipertanyakan, dalam arti dapat batal demi hukum dan/atau dapat dibatalkan oleh pihak ketiga yang berkepentingan.

Keempat syarat tersebut dapat dikelompokkan menjadi dua, yaitu:

1. Syarat (a) dan (b) merupakan syarat subyektif, karena mengenai para pihak atau subyek yang mengadakan perjanjian. Pelanggaran terhadap syarat subyektif, maka aktanya dapat dibatalkan.

2. Syarat (c) dan (d) merupakan syarat obyektif, karena berkaitan dengan isi perjanjian. Tidak dipenuhinyassyarat obyektif, maka akta batal demi hukum.

Pasal 39 ayat (1) Peraturan Pemerintah Nomor 24 Tahun 1997 Tentang Pendaftaran Tanah, pada bagian tugas dan jabatan, menyatakan: PPAT berwenang menolak untuk membuat akta apabila:

1. Mengenai bidang tanah yang sudah terdaftar atau hak milik atas satuan rumah susun, kepadanya tidak disampaikan sertipikat asli hak yang bersangkutan atau sertipikat yang diserahkan tidak sesuai dengan daftar-daftar yang ada di Kantor Pertanahan.

2. Mengenai bidang tanah yang belum terdaftar, kepadanya tidak disampaikan.

Ketentuan 1320 KUHPerdata apabilan dikaitkan dengan ketentuan Pasal 39 ayat (1) Peraturan Pemerintah Nomor 24 Tahun 1997 Tentang Pendaftaran Tanah, maka syarat materil dari prosedur pembuatan akta PPAT harus memenuhi syarat-syarat subyektif (subyek hak atau para pihak yang menghadap atau komparan) dan syarat obyektif (obyek hak yang dialihkan) dalam pembuatan akta PPAT. Apabila syarat subyektif dan obyektif dilanggar, maka akta PPAT tersebut dapat dimintai pembatalan dan/atau dinyatakan batal demi hukum. ${ }^{11}$

\section{Simpulan}

Berdasarkan uraian pembahasan pada bab sebelumnya, maka dapat ditarik beberapa simpulan, antara lain:

1. PPAT merupakan pejabat umum yang diberi kewenangan untuk membuat akta-akta otentik mengenai perbuatan hukum tertentu mengenai hak atas tanah atau hak milik atas satuan rumah susun. Kewenangan PPAT dalam konsep bestuurs bevoegdheid diperoleh secara delegasi dari pemerintah (BPN) yang menerima wewenang aslinya secara atributif. Pengalihan wewenang dari BPN kepada PPAT sebagai delegataris, mengakibatkan tanggung jawab dan tanggung gugat beralih pada delegataris (PPAT). Mendasarkan pada hal tersebut, maka BPN (pemberi wewenang) tidak dapat

11 Dhea Tri Febriana \& Ahars Sulaiman, Op.cit, hlm. 147. 
menggunakan wewenang itu lagi, kecuali setelah ada pencabutan dengan berpegang pada asas "contrarius actus".

2. PPAT sangat memungkinkan untuk melakukan suatu kekhilafan atau kekeliruan yang sifatnya administratif atau biasa disebut dengan mal administrasi. Konsekuensi hukum terhadap hal tersebut adalah PPAT dapat dimintai pertanggungjawabannya secara administratif. Tanggung jawab administratif atas mal administrasi yang dilakukan oleh PPAT akan menyebabkan PPAT tersebut terkena sanksi administrasi, yang dapat berupa: teguran, peringatan, schorsing, onzetting, dan pemberhentian dengan tidak hormat.

3. AktaPPAT yang tidak sesuai dengan prosedur pembuatan akta PPAT mengakibatkan akta tersebut menjadi cacat hukum (legal defect). Konsekuensi hukum dari akta PPAT yang cacat yuridis, yaitu: terdegradasinya kekuatan bukti sempurna dari akta otentik tersebut menjadi kekuatan bukti akta dibawah tangan apabila berdasarkan putusan pengadilan menyatakan adanya salah satu atau lebih pelanggaran yang dilakukan (pelanggaran terhadap syarat formil), dan akta PPAT dapat dibatalkan atau batal demi hukum dalam hal terjadi penyimpangan syarat materiil.

\section{DAFTAR PUSTAKA}

\section{Buku}

Hadjon Philipus M., 2015, Pengantar Hukum Administrasi Indonesia, Yogyakarta, Gadjah Mada University Press.

Harsono Boedi, 2003, Hukum Agraria Indonesia: Sejarah Pembentukan Undang-Undang Pokok Agraria, Isi dan Pelaksanaannya, Jakarta, Djambatan.

Subekti, 2001, Hukum Perjanjian, Jakarta, Intermasa.

Sutedi Adrian, 2008, Peralihan Hak Atas Tanah, Jakarta, Sinar Grafika.

\section{Peraturan Perundang-Undangan}

Undang-Undang Dasar Negara Republik Indonesia 1945.

Kitab Undang-Undang Hukum Perdata.

Undang-Undang Nomor 5 Tahun 1960 Tentang Peraturan Dasar Pokok-Pokok Agraria.

Undang-Undang Nomor 28 Tahun 2009 Tentang Pajak Daerah Dan Retribusi Daerah.

Undang-Undang Nomor 9 Tahun 2004 Tentang Perubahan Atas Undang-Undang Nomor 5 Tahun 1986 Tentang Peradilan Tata Usaha Negara.

Undang-Undang Nomor 5 Tahun 1986 Tentang Peradilan Tata Usaha Negara.

Peraturan Pemerintah Nomor 24 Tahun 1997 Tentang Pendaftaran Tanah. 
Peraturan Pemerintah Nomor 37 Tahun 1998 Tentang Peraturan Jabatan Pejabat Pembuat Akta Tanah.

Peraturan Pemerintah Republik Indonesia Nomor 24 Tahun 2016 Tentang Perubahan Atas Peraturan Pemerintah Nomor 37 Tahun 1998 Tentang Peraturan Jabatan Pejabat Pembuat Akta Tanah.

Peraturan Kepala Badan Pertanahan Nasional Nomor 1 Tahun 20016 Tentang Ketentuan Pelaksanaan Peraturan Pemerintah Nomor 37 Tahun 1998 Tentang Peraturan Jabatan Pejabat Pembuat Akta Tanah.

\section{Jurnal}

Christin Dona, "Analisis Atas Diketahuinya Cacat Yuridis Pada Akta Jual Beli Tanah Dan Rumah Yang Dibuat Oleh PPAT (Putusan Mahkamah Agung No. 2333 K/Pdt/2015)", Premise Law Journal, Vol. 14, Issue 3, 2017.

Jimly Asshiddiqie, "Independensi Dan Akuntabilitas Pejabat Pembuat Akta Tanah", Jurnal Renvoi, Vol. 3, Juni 2003.

Tri Febriana Dhea \& Sulaiman Ahars, "Tanggung Jawab Pejabat Pembuat Akta Tanah (PPAT) Dalam Pembuatan Akta Jual Beli Tanah Berdasarkan Peraturan Pemerintah Republik Indonesia Nomor 24 Tahun 2016 Tentang PPAT", Jurnal Petita, Vol. 1, No. 1, Juni 2019.

Yoga Prawira I Gusti Bagus, "Tanggung Jawab PPAT Terhadap Akta Jual Beli Tanah", Jurnal IUS, Vol. 4, No. 1, April 2016.

\section{Lain-lain}

Tim Penyusun Naskah Akademik dan Rancangan Undang-Undang Tentang Jabatan Pejabat Pembuat Akta Tanah, 2019, Naskah Akademik dan Rancangan Undang-Undang Tentang Jabatan Pejabat Pembuat Akta Tanah, Jakarta, Badan Keahlian Dewan Perwakilan Rakyat Republik Indonesia. 